\title{
In vivo effects of interferon- $\gamma$ and anti-interferon- $\gamma$ antibody on the experimentally induced lichenoid tissue reaction
}

\author{
T. SHIOHARA, B.J.NICKOLOFF, ^ N.MORIYA, C.GOTOH AND \\ M.NAGASHIMA \\ Department of Dermatology, Kyorin University School of Medicine, Tokyo, Japan and ${ }^{\text {Departments of }}$ \\ Pathology and Dermatology, University of Michigan Medical Center, Ann Arbor, U.S.A.
}

Accepted for publication 23 February 1988

\section{SUMMARY}

We investigated the in vivo effect of recombinant interferon- $\gamma(\mathrm{IFN}-\gamma)$ and tumour necrosis factor $\alpha$ (TNF- $\alpha$ ) treatment of mice on the development of the delayed-type hypersensitivity (DTH) reaction and lichenoid tissue reaction (LTR) following the local injection of cloned autoreactive T cells. Both the DTH reaction and the LTR were significantly enhanced by pretreatment with IFN- $\gamma$, but not with $\mathrm{TNF}-\alpha$. Induction of class II MHC antigens on keratinocytes was not essential for the enhancement by IFN- $\gamma$. Administration of anti-IFN- $\gamma$ antibody reduced the DTH reaction and LTR, although complete inhibition was not observed with our treatment regimen. The ability of IFN- $\gamma$ to increase the number of the cloned T cells invading the epidermis in vivo, is in keeping with our previous observation that IFN- $\gamma$ treatment of cultured keratinocytes markedly increased the adherence reaction between $\mathrm{T}$ cells and keratinocytes in vitro.

Interferon- $\gamma(\mathrm{IFN}-\gamma)$ is a lymphokine produced by $\mathrm{T}$ cells upon activation by an antigen or mitogen. In addition to its antiviral and antiproliferative activities, ${ }^{1}$ IFN- $\gamma$ has a number of effects which favour the development of inflammation: it induces the expression of class II major histocompatibility complex (MHC) antigens on normally negative cells including keratinocytes, ${ }^{2}$ enhances lymphocyte adhesion molecule expression by monocytes, ${ }^{3}$ functions as a macrophage-activating factor, ${ }^{4}$ and augments the phagocytic and cytotoxic activities of neutrophils. ${ }^{5}$ Aberrant expression of class II MHC antigens on normally negative cells in a variety of autoimmune diseases ${ }^{6}$ and the modulation of this expression by IFN $-\gamma^{2}$ raise the intriguing possibility that unregulated production of IFN- $\gamma$ may be central to the development of autoimmunity. ${ }^{7}$

Correspondence: Tetsuo Shiohara, Department of Dermatology, Kyorin University School of Medicine, 6-20-2 Shinkawa, Mitaka, Tokyo, Japan. 
We have recently demonstrated that murine autoreactive cloned $\mathrm{T}$ cells capable of producing IFN- $\gamma$ and tumour necrosis factor $\beta$ (TNF- $\beta$ ) evoke the cutaneous delayed-type hypersensitivity (DTH) reaction and lichenoid tissue reaction (LTR) upon intradermal inoculation into normal syngeneic hosts. ${ }^{8}$ The LTR evoked by these T cells was most probably mediated by a synergistic effect between IFN- $\gamma$ and TNF- $\beta$ released from the T cells in situ. ${ }^{9,10}$ Since IFN- $\gamma$ has been observed to greatly enhance the adherence reaction between $\mathrm{T}$ cells and cultured keratinocytes in vitro, ${ }^{11}$ we investigated the possibility of an in vivo counterpart of this reaction. These findings led us to investigate the in vivo effect of recombinant IFN- $\gamma$ and anti-IFN- $\gamma$ antibody on the development of the lichenoid tissue reaction.

\section{METHODS}

\section{Animals}

Female $\mathrm{C}_{57} \mathrm{BL} / 6$ (B6) mice were obtained from Charles River Japan, Inc. and maintained in our animal facility. They were used predominantly at 8 to 12 weeks of age.

\section{Induction of the lichenoid tissue reaction}

Two different kinds of autoreactive cloned $\mathrm{T}$ cells specific for class II MHC antigens, I- $\mathrm{A}^{\mathrm{b}}$, were established in previous experiments. ${ }^{9,10} \mathrm{BB} 5$ cells, when injected into the footpads of syngeneic B6 mice, migrate into the epidermis and cause the destruction of the epidermal cells. ${ }^{8}$ Cro cells, in contrast, are completely incapable of migrating into the epidermis and consequently fail to induce the epidermal change. ${ }^{8}$

\section{Assay for the delayed type hypersensitivity reaction}

The cloned $T$ cells were harvested from culture 7-8 days after antigenic stimulation. The $T$ cells with a viability greater than $95 \%$ were injected intradermally, at different doses and in a volume of $25 \mu \mathrm{l}$, into the hind footpads of B6 mice. The resultant swelling of the footpads was measured with a dial thickness gauge $48 \mathrm{~h}$ after injection, as described previously. ${ }^{8}$

\section{Evaluation of the lichenoid tissue reaction}

At $72 \mathrm{~h}$ after injection of the $\mathrm{T}$ cells, skin samples from the hind footpads of the mice were excised using scissors, fixed in $3.7 \%$ buffered formaldehyde, embedded in paraffin, sectioned, and stained with haematoxylin and eosin. The LTR was defined as the intensity of epidermal invasion by the injected $\mathrm{T}$ cells as follows. A semi-quantitative evaluation of epidermal invasion by the injected $T$ cells was performed by counting lymphoid cells within the epidermis. At least 30 serial sections from each individual footpad were examined, and of these the six sections in which the epidermis was regarded to be most heavily infiltrated with lymphoid cells were counted. The results were expressed as the number of lymphoid cells per linear mm of epidermis, as previously described. ${ }^{8}$

\section{Reagents}

Recombinant mouse IFN- $\gamma\left(0.98 \mathrm{mg} / \mathrm{ml}\right.$; specific activity: $\left.23 \times 10^{6} \mathrm{U} / \mathrm{ml}\right)$, purified rabbit antibody against mouse IFN $-\gamma\left(\mathrm{I} \cdot 2 \mathrm{mg} / \mathrm{ml} ; \mathrm{I} \mathrm{ml}\right.$ of antibody neutralizes $\mathrm{I} \cdot 28 \times 10^{5} \mathrm{U}$ of IFN- $\gamma$ ) and recombinant human TNF- $\alpha\left(0.50 \mathrm{mg} / \mathrm{ml}\right.$; specific activity: $\left.2.5 \mathrm{I} \times 10^{7} \mathrm{U} / \mathrm{ml}\right)$ were a gift from Dr. H.M.Shepard (Genetech, Inc., South San Francisco, CA, U.S.A.). They were stored at $4{ }^{\circ} \mathrm{C}$ and diluted in phosphate-buffered saline (PBS) before use. IFN- $\gamma$ or TNF- $\alpha$ was injected intradermally into the hind footpads of B6 mice on 2 or 6 successive days at a dose of $0.5-5 \times 10^{4}$ 
$\mathrm{U} /$ day. Control mice received the corresponding quantities of PBS alone. In some experiments, on days $O$ and $\mathrm{I}$ or $\mathrm{I}$ and 2, anti-IFN- $\gamma$ antibody $(50 \mu \mathrm{l})$ was injected into the same footpad site that had received $\mathrm{BB}_{5}$ cells on day o. In these experiments, control mice received $50 \mu \mathrm{l}$ PBS containing $60 \mu \mathrm{g}$ of chromatographically purified rabbit IgG (Cappel Laboratories, Cochville, PA, U.S.A.). Because no significant changes were observed between mice injected with PBS alone and those injected with rabbit IgG-containing PBS, with respect to footpad swelling and histology, the latter mice were used as the proper controls in these experiments.

\section{RESULTS}

Local administration of IFN- $\gamma$ enhanced the DTH reaction and lichenoid tissue reaction induced by the autoreactive $T$ cells

To elucidate the effect of IFN- $\gamma$ in-vivo on the DTH reaction and LTR induced by the local transfer of the autoreactive $\mathrm{T}$ cells, groups of normal B6 mice were pre-treated by the intradermal injection with $0.5 \times 10^{4} \mathrm{U}$ of either IFN- $\gamma$ or TNF- $\alpha$ on the two days preceeding injection of the T cells. This dose of IFN- $\gamma$ or TNF- $\alpha$ was selected because in the absence of added autoreactive $\mathrm{T}$ cells, it has been found not to evoke significant pathological changes. On day $0, \mathrm{I} \times 10^{6} \mathrm{BB} 5$ cells were injected into the same site that had been injected with IFN $-\gamma$, TNF- $\alpha$ or PBS. As shown in Table I and Fig. I, pre-treatment with IFN- $\gamma$ significantly enhanced the epidermal invasion by $\mathrm{BB}_{5}$ cells and, to a lesser extent, the DTH reaction, while the effect of TNF- $\alpha$ in vivo was slight. When $\mathrm{BB}_{5}$ cells were given at a lower dose $\left(0.5 \times 10^{6}\right.$ cells $/$ mouse), the enhancement was more pronounced. Moreover, concomitant injection of antiIFN- $\gamma$ antibody with IFN $-\gamma$ abrogated its ability to enhance the DTH reaction and LTR induced by $\mathrm{BB}_{5}$ cells. However, when IFN- $\gamma$ was injected after the injection of $\mathrm{BB}_{5}$ cells, the enhancement was found to be minimal. Compared with treatment with IFN- $\gamma$ alone, no augmentation was observed after simultaneous treatment with IFN- $\gamma$ and TNF- $\alpha$. We then

TABLE I. Ability of IFN- $\gamma$ to enhance the DTH reaction and LTR

\begin{tabular}{|c|c|c|c|c|}
\hline \multirow{2}{*}{$\begin{array}{l}\text { No. of T cells } \\
\text { injected }\end{array}$} & \multicolumn{2}{|c|}{ Treatment } & \multirow{2}{*}{$\begin{array}{c}\text { Increase in footpad } \\
\text { thickness }\left(\mathrm{mm} \times \mathrm{IO}^{-2}\right) \\
\text { mean } \pm \mathrm{SD}\end{array}$} & \multirow{2}{*}{$\begin{array}{l}\text { Lymphoid cells invading } \\
\text { the epidermis } \\
(\text { cells } / \mathrm{mm}) \text { mean } \pm \mathrm{SD}\end{array}$} \\
\hline & Agent & Injection on day & & \\
\hline \multicolumn{5}{|l|}{ Experiment I } \\
\hline $\mathrm{I} \times 10^{6} \mathrm{BB}_{5}$ & PBS & $-2,-1$ & $32 \cdot 5 \pm 2 \cdot 3$ & $95 \pm 6$ \\
\hline $\mathrm{I} \times 10^{6} \mathrm{BB}_{5}$ & IFN- $\gamma$ & $-2,-I$ & $37 \cdot 8 \pm 1 \cdot 9^{\star}$ & $171 \pm 9^{\star \star}$ \\
\hline $\mathrm{I} \times 10^{6} \mathrm{BB} 5$ & TNF- $\alpha$ & $-2,-I$ & $36 \cdot 8 \pm 2 \cdot 9$ & $108 \pm I I$ \\
\hline $\mathrm{I} \times 10^{6} \mathrm{CrO}$ & PBS & $-2,-1$ & $16 \cdot 3 \pm 1 \cdot 2$ & 0 \\
\hline $\mathrm{I} \times 10^{6} \mathrm{CrO}$ & IFN- $\gamma$ & $-2,-I$ & $20 \cdot 7 \pm 1 \cdot 7^{\star}$ & 0 \\
\hline \multicolumn{5}{|l|}{ Experiment 2} \\
\hline $0.5 \times 10^{6} \mathrm{BB}_{5}$ & PBS & $-2,-I$ & $21 \cdot 0 \pm 2 \cdot 7$ & $24 \pm 3$ \\
\hline $0.5 \times 10^{6} \mathrm{BB}_{5}$ & IFN- $\gamma$ & $-2,-I$ & $26 \cdot 3 \pm 2 \cdot 4^{\star}$ & $5 I \pm 9^{\star \star}$ \\
\hline $0.5 \times 10^{6} \mathrm{BB}_{5}$ & IFN- $\gamma+$ anti-IFN- $\gamma$ & $-2,-I$ & $18 \cdot 8 \pm 1 \cdot 9$ & $20 \pm 3$ \\
\hline $0.5 \times 10^{6} \mathrm{BB} 5$ & $\mathrm{IFN}-\gamma+\mathrm{TNF}-\alpha$ & $-2,-I$ & $25 \cdot 8 \pm \mathrm{I} \cdot 8^{\star}$ & $55 \pm 6^{\star \star}$ \\
\hline $0.5 \times 10^{6} \mathrm{BB}_{5}$ & IFN- $\gamma$ & $\mathbf{I , 2}$ & $19 \cdot 8 \pm 2 \cdot 1$ & $28 \pm 2^{\star}$ \\
\hline
\end{tabular}

Values are means \pm SD of 3-4 mice.

Significantly different from control; ${ }^{\star} P<0.05,{ }^{\star \star} P<0.005$ (Student's $t$-test). 

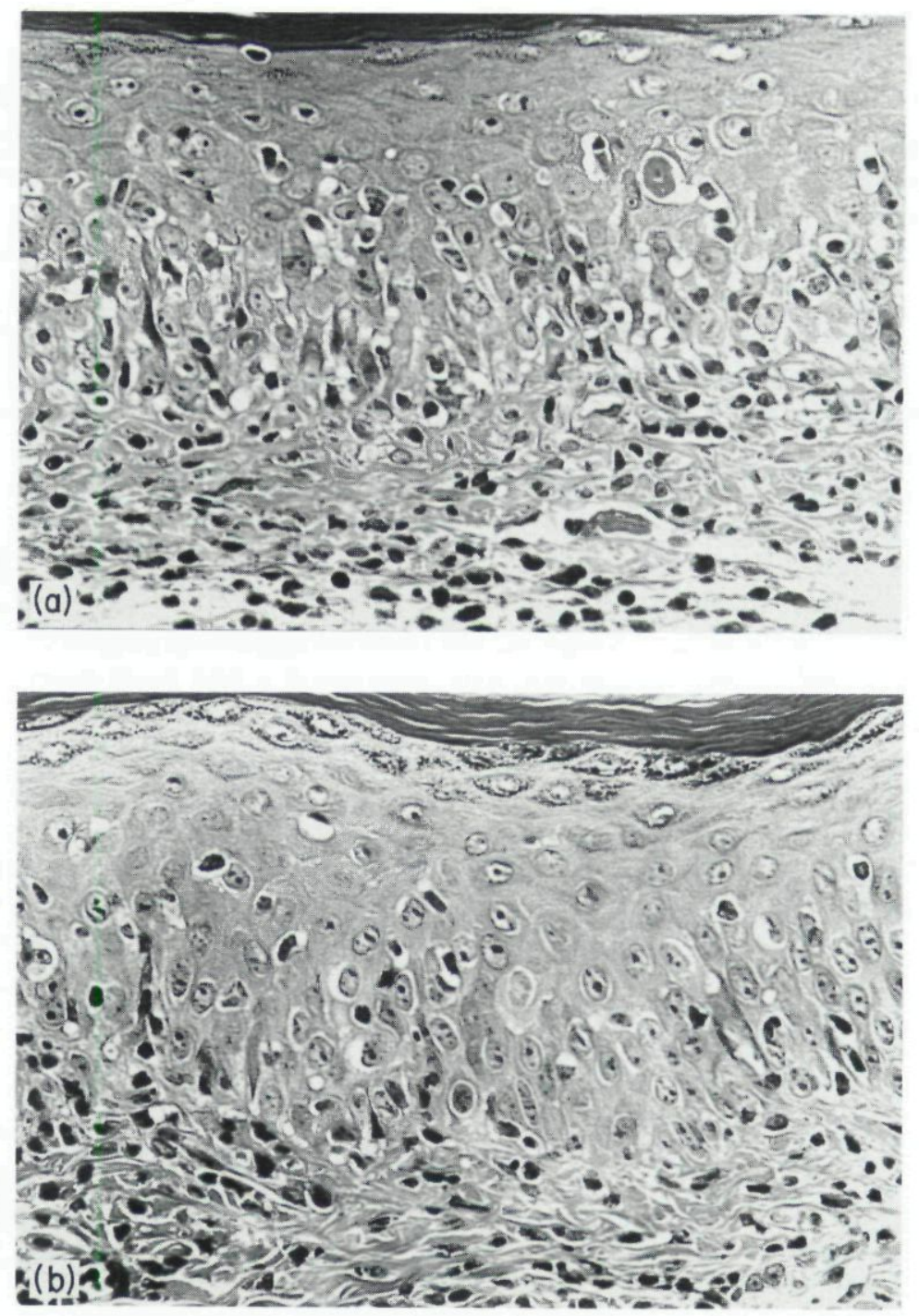

FIGURE I. Epidermal invasion of BB5 cells $72 \mathrm{~h}$ after injection of $\mathrm{I} \times 10^{6}$ cells into the footpads of syngeneic mice who had been injected at the same site on the 2 preceeding days with (a) IFN- $\gamma$ $0.5 \times 10^{4} \mathrm{U}$ or (b) PBS. (H\&E; original $\left.\times 120\right)$.

investigated whether local administration of IFN- $\gamma$ could induce a non-epidermotropic clone, Cro, to migrate into the epidermis. In contrast to the enhanced migration of BB5 cells, $\mathrm{Cr}_{1}$ cells were still incapable of migrating into the epidermis after in vivo treatment with IFN- $\gamma$, although the DTH reaction was similarly enhanced.

The ability of IFN- $\gamma$ to enhance the DTH responses and LTR is not mediated through the induction of $I-A$ antigens by keratinocytes

It has been suggested that the expression of I-A (class II MHC antigens in mice) by keratinocytes may help direct the migration of lymphocytes into the skin during DTH 
TABLE 2. Effect of multiple IFN- $\gamma$ administration on the DTH reaction and LTR

\begin{tabular}{|c|c|c|c|c|}
\hline \multirow{2}{*}{$\begin{array}{l}\text { No. of BB5 } \\
\text { cells injected }\end{array}$} & \multicolumn{2}{|c|}{ Treatment } & \multirow{2}{*}{$\begin{array}{c}\text { Increase in } \\
\text { footpad thickness } \\
\left(\mathrm{mm} \times \mathrm{IO}^{-2}\right) \text { mean } \pm \mathrm{SD}\end{array}$} & \multirow{2}{*}{$\begin{array}{l}\text { Lymphoid cells invading } \\
\text { the epidermis } \\
\text { (cells } / \mathrm{mm}) \text { mean } \pm \mathrm{SD}\end{array}$} \\
\hline & Agent & Injection on day & & \\
\hline $1 \times 10^{6}$ & PBS & $-6,-5,-4,-3,-2,-I$ & $28 \cdot 8 \pm \mathrm{I} \cdot \mathrm{I}$ & $53 \pm 7$ \\
\hline $1 \times 10^{6}$ & $\mathrm{IFN}-\gamma\left(5 \times 10^{4} \mathrm{U}\right)$ & $-6,-5,-4,-3,-2,-I$ & $37 \cdot 0 \pm 2 \cdot 9^{\star}$ & $185 \pm 13^{\star \star}$ \\
\hline
\end{tabular}

Values are means \pm SD of 4 mice.

Significantly different from control; ${ }^{\star} P<0.05,{ }^{\star}{ }^{*} P<0.005$ (Student's $t$-test).

responses. ${ }^{12} \mathrm{We}$, therefore, tested whether the ability of IFN- $\gamma$ to induce keratinocytes to express I-A antigens was involved in the observed enhancement of the DTH reaction and LTR by IFN $-\gamma$. However, after in vivo treatment with $0.5 \times 10^{4} \mathrm{U} \mathrm{IFN}-\gamma$ for 2 days, the epidermis did not show intercellular staining for I-A antigens, as judged by indirect immunofluorescence staining of frozen sections of footpad skin. The induction of I-A antigens on keratinocytes was found to be obtained with $5 \times 10^{4} \mathrm{U}$ IFN- $\gamma$ given on 6 consecutive days (data not shown). The repeated intradermal injections with this dose of IFN- $\gamma$ were, however, usually associated with a significant increase in dermal infiltrates, that were not observed in mice injected with $0.5 \times 10^{4}$ $\mathrm{U}$ IFN $-\gamma$ on 2 consecutive days. However, no intra-epidermal lymphoid cells were observed in mice that had received $5 \times 10^{4} \mathrm{IFN}-\gamma$ for 6 days, but not followed by the injection of $\mathrm{BB} 5$ cells. As shown in Table 2, 6 days of treatment with higher doses $\left(5 \times 10^{4} \mathrm{U}\right)$ of IFN- $\gamma$ markedly enhanced the DTH reaction and LTR. These results suggest that the enhancement by IFN- $\gamma$ could be dose-dependent, although we cannot exclude the possibility that the higher dose of IFN $-\gamma$ would have resulted in endogenous IFN $-\gamma$ production by host lymphocytes, thus contributing to some of the observed enhancement.

\section{Treatment with anti-IFN- $\gamma$ antibody reduced the $D T H$ reaction and $L T R$}

In order to test whether anti-IFN- $\gamma$ antibody could prevent the development of the LTR, mice that had received $\mathrm{I} \times \mathrm{IO}^{6} \mathrm{BB} 5$ cells were given intradermal injections with anti-IFN- $\gamma$ antibody $(50 \mu \mathrm{l})$. Preliminary studies indicated that treatment of normal mice with this dose of anti-IFN- $\gamma$ antibody elicited neither significant dermal infiltration, nor footpad swelling. As shown in Table 3 , administration of anti-IFN- $\gamma$ antibody significantly reduced the DTH reaction and epidermal invasion by $\mathrm{BB}_{5}$ cells when the administration was delayed to day $\mathrm{I}$ after injection of BB5 cells. In contrast, prevention of the DTH reaction and LTR by anti-IFN $-\gamma$ antibody was not observed when mice were injected with the antibody immediately after the injection of $\mathrm{BB}_{5}$ cells. The degree of inhibition by anti-IFN- $\gamma$ antibody was more profound in the DTH reaction than in the LTR. However, two intradermal injections of anti-IFN- $\gamma$ antibody at $24 \mathrm{~h}$ intervals did not completely abrogate the capacity of $\mathrm{BB}_{5}$ cells to elicit the DTH reaction and LTR.

\section{DISCUSSION}

To clarify the role of IFN- $\gamma$ in the pathogenesis of the lichenoid tissue reaction, we treated mice with repeated injections of recombinant mouse IFN- $\gamma$ before the local injection of cloned T cells capable of inducing the LTR. The treatment enhanced the DTH reaction and the LTR induced by the $\mathrm{T}$ cells. This enhancement appeared not to be due to the induction of I-A antigens on 
TABLE 3. Effect of anti-IFN- $\gamma$ antibody on the DTH reaction and LTR

\begin{tabular}{|c|c|c|c|c|}
\hline \multirow{2}{*}{$\begin{array}{l}\text { No. of } \\
\text { BB5 cells } \\
\text { injected }\end{array}$} & \multicolumn{2}{|c|}{ Treatment } & \multirow{2}{*}{$\begin{array}{c}\text { Increase in } \\
\text { footpad thickness } \\
\left(\mathrm{mm} \times 10^{-2}\right) \text { mean } \pm \mathrm{SD}\end{array}$} & \multirow{2}{*}{$\begin{array}{l}\text { Lymphoid cells invading } \\
\text { the epidermis } \\
(\text { cells } / \mathrm{mm}) \text { mean } \pm \mathrm{SD}\end{array}$} \\
\hline & Agent & Injection on day & & \\
\hline \multicolumn{5}{|c|}{ Experiment I } \\
\hline $1 \times 10^{6}$ & PBS & o & $30 \cdot 3 \pm 3 \cdot 8$ & $95 \pm 6$ \\
\hline$I \times 10^{6}$ & anti-IFN- $\gamma$ & ○ & $33 \cdot 3 \pm 2 \cdot 2$ & $102 \pm 16$ \\
\hline$I \times 10^{6}$ & PBS & I & $32 \cdot 5 \pm 2 \cdot 3$ & $99 \pm 8$ \\
\hline $1 \times 10^{6}$ & anti-IFN- $\gamma$ & I & $22 \cdot 8 \pm 2 \cdot 4^{\star \star}$ & $80 \pm 10^{\star}$ \\
\hline \multicolumn{5}{|c|}{ Experiment 2} \\
\hline$I \times 10^{6}$ & PBS & I & $35 \cdot 2 \pm 3 \cdot I$ & $8 I \pm 10$ \\
\hline $1 \times 10^{6}$ & anti-IFN- $\gamma$ & I & $27 \cdot 5 \pm 2 \cdot I^{\star}$ & $72 \pm 6$ \\
\hline$I \times 10^{6}$ & PBS & $\mathrm{I}, 2$ & ND & $89 \pm 7$ \\
\hline$I \times 10^{6}$ & anti-IFN- $\gamma$ & $\mathrm{I}, 2$ & ND & $62 \pm 7^{\star \star}$ \\
\hline
\end{tabular}

keratinocytes by IFN- $\gamma$, because I-A antigen expression on keratinocytes was never observed in footpads injected with the lower dose of IFN $-\gamma$ on 2 consecutive days, where both the DTH reaction and LTR were significantly enhanced. It has been proposed that in the LTR, IFN- $\gamma$ secreted by activated lymphocytes in the upper dermis could induce basal keratinocytes to express class II MHC antigens in a wide variety of dermatose $\mathrm{s}^{13}$ and that I-A antigen expression by keratinocytes may permit them to function as antigen-presenting cells, like Langerhans cells. ${ }^{14}$ However, experimental evidence has recently been presented to challenge such a hypothesis. Gaspari et al. ${ }^{15}$ have shown that class II antigen positive keratinocytes do not replace Langerhans cells in their capacity to induce various immune responses. Our present finding also argues against the critical role of class II antigen positive keratinocytes in the induction of the LTR, although our failure to detect I-A antigens on keratinocytes after treatment with the lower dose of IFN $-\gamma$ does not necessarily exclude their presence, or their appearance later and possible significance in perpetuating the inflammatory response.

What, then, is the mechanism by which IFN- $\gamma$ enhances the DTH reaction and LTR? IFN- $\gamma$ has been shown to induce synthesis of TNF receptors in some cells and thereby increase their sensitivity to the cytostatic activity of TNF. ${ }^{16}$ It is, therefore, possible that exogenous IFN- $\gamma$ may act to increase TNF receptors on keratinocytes, thereby rendering them more sensitive to TNF released from activated $\mathrm{T}$ cells and macrophages. In addition, IFN- $\gamma$ preferentially enhances the interleukin I (IL-I) secretory potential of monocytes. ${ }^{17}$ Because epidermal cellderived thymocyte-activating factor (ETAF)/IL-I has been reported to be a potent chemoattractant for T cells, ${ }^{18}$ IFN- $\gamma$ may act to enhance the migration of $\mathrm{T}$ cells into the epidermis, through its capacity to stimulate keratinocytes to release ETAF.

With respect to a role for IFN- $\gamma$ in promoting $\mathrm{T}$ cell adhesion to keratinocytes, we have recently observed that IFN- $\gamma$-treated keratinocytes display a markedly increased adherence reaction towards monocytes and $\mathrm{T}$ lymphocytes. ${ }^{11,19} \mathrm{This}$ adherence reaction did not appear to involve class II antigens, as antibody to this antigen did not inhibit the reaction, but antibody against lymphocyte function-associated antigen I (LFA-I) totally blocked the binding. Thus, it is possible that IFN- $\gamma$ increased the number of $\mathrm{BB}_{5}$ cells in the epidermis by promoting the 
adherence reaction between lymphocytes and keratinocytes in vivo as we have previously observed in vitro. In fact, the kinetics of the reaction in vivo agree well with our in vitro observations ${ }^{19}$ in which significant enhancement of binding by IFN- $\gamma$ was seen between $\mathrm{I}$ and 2 days. When we compared IFN- $\gamma$ to TNF- $\alpha$ in the in vitro adherence assay, IFN- $\gamma$ was better than TNF, and the failure to observe significant changes with TNF- $\alpha$ in the present in vivo study may reflect the requirement for higher concentrations of TNF- $\alpha$ to be used than could be achieved in the present study.

It has been shown that $\mathrm{TNF}-\alpha$ and $-\beta$, secreted by macrophages and lymphocytes, respectively, share several activities with IFN- $\gamma$, including cytotoxic or cytostatic effects ${ }^{20}$ and ability to enhance the expression of a family of leukocyte adhesion molecules. ${ }^{21}$ Moreover, the synergistic effect of the two lymphokines is frequently observed ${ }^{22}$ and most IFN- $\gamma$-producing $\mathrm{T}$ cells as well as our cloned $\mathrm{T}$ cells can also release TNF- $\beta$ (N.H. Ruddle, personal communication). ${ }^{23}$ It is possible, therefore, that the two lymphokines could exist in combination, but not in isolation, in the physiological environment. However, the apparent incapacity of TNF- $\alpha$ to enhance the LTR and to act synergistically with IFN $-\gamma$ suggests that the enhancement of the LTR may be a property unique to IFN- $\gamma$. Alternatively, because TNF treatment has been reported to result in synthesis of prostaglandins, ${ }^{24}$ the capacity of TNF- $\alpha$ to enhance the DTH reaction and the LTR may have been abrogated through the generation of prostaglandins, which has been shown to suppress cell-mediated immune responses including DTH reactions.

In the light of the crucial role of IFN- $\gamma$ in the pathogenesis of the LTR, administration of anti-IFN $-\gamma$ antibody might constitute an effective strategy for the treatment of various lichenoid skin diseases. Our results show that although partial prevention of the LTR was achieved by treatment with anti-IFN- $\gamma$ antibody, the reduction was less pronounced than expected from the in vivo enhancing effect of IFN- $\gamma$. The reason why the DTH reaction and LTR were not completely abrogated by anti-IFN- $\gamma$ antibody treatment is not clear, but might have simply been due to use of anti-IFN- $\gamma$ antibody at insufficient concentrations, or failure to maintain effective concentrations for a sufficiently long period to neutralize IFN- $\gamma$ released from activated $\mathrm{T}$ cells in situ. Thus, it remains to be determined whether treatment with anti-IFN- $\gamma$ antibody could be a useful therapeutic approach to LTR and other autoimmune diseases, as is the case with antibodies to $\mathrm{T}$ cell surface molecules. ${ }^{25}$

\section{REFERENCES}

I Trinchieri G, Perussia B. Immune interferon: a pleiotropic lymphokine with multiple effects. Immunol Today I985; 6: $131-6$.

2 Basham TY, Nickoloff BJ, Merigan TC, Morhenn VB. Recombinant gamma interferon induces HLA-DR expression on cultured human keratinocytes. F Invest Dermatol 1984; 83: 88-91.

3 Metzer SJ, Faller DV, Burakoff SJ. Interferon- $\gamma$ induction of LFA-I-mediated homotypic adhesion of human monocytes. F Immunol 1986; 137: 108-13.

4 Schulz RM, Kleinschmidt WJ. Functional identity between murine recombinant gamma interferon (IFN- $\gamma)$ and macrophage activating factor. Nature 1983; 305: 239-40.

5 Shalaby MR, Aggarwal BB, Rinderknecht E et al. Activation of human polymorphonuclear neutrophil functions by interferon- $\gamma$ and tumor necrosis factors. F Immunol 1985; 135: 2069-73.

6 Londei M, Bottazzo GF, Feldmann M. Human T-cell clones from autoimmune thyroid glands: specific recognition of autologous thyroid cells. Science $1985 ; 228$ : 85-9.

7 Rosenberg YJ, Steinberg AD, Santoro TJ. The basis of autoimmunity in MRL-lpr/lpr mice: a role for self Iareactive T cells. Immunol Today $1984 ; 5: 64-7$.

8 Shiohara T, Moriya N, Mochizuki T, Nagashima M. Lichenoid tissue reaction (LTR) induced by local transfer of 
Ia-reactive T cell clones. II. L TR by epidermal invasion of cytotoxic lymphokine-producing autoreactive T cells. $f$ Invest Dermatol 1987; 89: 8-I4.

9 Shiohara T, Ruddle NH, Horowitz M et al. Anti-tumor activity of class II MHC antigen-restricted cloned autoreactive T cells. I. Destruction of B16 melanoma cells mediated by bystander cytolysis in vitro. F Immunol I987; 138: $1971-8$.

Io Shiohara T, Moellmann G, Jacobson K et al. Anti-tumor activity of class II MHC antigen-restricted cloned autoreactive T cells. II. Novel immunotherapy of BI 6 melanomas by local and systemic adoptive transfer. $\mathcal{F}$ Immunol 1987; 138: 1979-86.

II Nickoloff BJ, Lewinsohn DM, Butcher EC. Enhanced binding of peripheral blood mononuclear leukocytes to $\gamma$ interferon-treated cultured keratinocytes. Am f Dermatopathol 1987; 9: 413-8.

I2 Roberts LK, Spangrude GJ, Daynes RA et al. Correlation between keratinocyte expression of Ia and the intensity and duration of contact hypersensitivity responses in mice. F Immunol $1985 ; 135: 2929-36$.

I3 Nickoloff BJ, Basham TY, Merigan TC et al. Keratinocyte class II histocompatibility antigen expression. $B r f$ Dermatol 1985; 112: 373.

I4 Morhenn VB. The etiology of lichen planus. A hypothesis. Am f Dermatopathol 1986; 8: 154-6.

I5 Gaspari AA, Katz SI. Induction and functional characterization of class II antigens on murine keratinocytes. $f$ Invest Dermatol 1987; 88: 490 (abstract).

I6 Tsujimoto M, Yip YM, Viocek J. Interferon- $\gamma$ enhances expression of cellular receptors for tumor necrosis factor. $\mathcal{f}$ Immunol 1986; 136: 2442-4.

17 Arenzana-seisdedos F, Virelizeir JL, Fiers W. Interferons as macrophage-activating factors. III. Preferential effects of interferon- $\gamma$ on the interleukin I secretory potential of fresh or aged human monocytes. $f$ Immunol 1985; 134: $2444-8$.

I8 Sauder DN, Monick MM, Hunninghake GW. Epidermal cell-derived thymocyte activating factor (ETAF) is a potent T-cell chemoattractant. F Invest Dermatol 1985; 85: 43I-3.

19 Nickoloff BJ, Lewinsohn DM, Butcher EC et al. Recombinant gamma interferon increases the binding of peripheral blood mononuclear leukocytes and a Leu- $3^{+} \mathrm{T}$ lymphocyte cell clone to cultured keratinocytes and a malignant cutaneous squamous carcinoma cell line which is blocked by antibody against the LFA-I molecule. $f$ Invest Dermatol 1988; 90: 17-22.

20 Old LJ. Tumor necrosis factor (TNF). Science 1985; 230: 630-2.

2I Dustin ML, Rothlein R, Bhan AK et al. Induction by IL I and interferon: tissue distribution, biochemistry, and function of a natural adherence molecule (ICAM-I). F Immunol 1986; 137: I270-4.

22 Lee SH, Aggarwal BB, Rinderknecht E et al. The synergistic anti-proliferative effect of $\gamma$-interferon and human lymphotoxin. F Immunol 1984; 133: 1083-6.

23 Tite JP, Powell MB, Ruddle NH. Protein-antigen specific Ia-restricted cytolytic T cells; analysis of frequency, target cell susceptibility, and mechanism of cytolysis. F Immunol 1985; 135: 24-33.

24 Ruddle NH. Tumor necrosis factor and related cytotoxins. Immunol Today 1987; 8: 129-30.

25 Wofsy D, Seaman WE. Reversal of advanced murine lupus in NZB/NZW $\mathrm{F}_{1}$ mice by treatment with monoclonal antibody to $\mathrm{L}_{3} \mathrm{~T}_{4}$. . I Immunol $1987 ; \mathbf{1 3 8}$ : 3247-53. 
This document is a scanned copy of a printed document. No warranty is given about the accuracy of the copy. Users should refer to the original published version of the material. 